\title{
Impact of sewage sludge and composts prepared from sewage sludge on the content and uptake of macronutrients by straw of miscanthus sacchariflorus
}

\author{
Anna Iżewska, Edward Krzywy, Krzysztof Balcer \\ University of Agriculture, Department of Environmental Chemistry, ul. J. Stowackiego 17, 71-434 Szczecin, Poland, \\ e-mail: izewska@agro.ar.szczecin.pl
}

\begin{abstract}
The pot experiment was set up under the conditions of the hall of vegetation in 2002. The municipal sewage sludge and composts produced with the GWDA method in 2001 based on municipal sewage sludge with the $30 \%$ addition of structuring materials, in conversion to the dry matter, were used in the experiment. The pot experiment was set up with the split-split-plot method in three repetitions. The objects of the first factor were the doses of sewage sludge and composts $(1$ dose $=13 \mathrm{~g}, 2$ dose $=26 \mathrm{~g}, 3$ dose $=39 \mathrm{~g}, 4$ dose $=$ $52 \mathrm{~g}$ of dry matter in relation to the soil weight in the pot), the objects of the second factor were the types of organic fertilization (sewage sludge, 0,5-year compost prepared from sewage sludge, 1,5-year compost prepared from sewage sludge), objects of the third factor were the variants with and without nitrogen and potassium fertilization in the rates of $0.27 \mathrm{~g} \mathrm{~N}$ and $0.26 \mathrm{~g} \mathrm{~K}$ per pot. The experiment was conducted in KickBrauckmann`s pots of $9 \mathrm{dm}^{3}$ capacity in which $8 \mathrm{~kg}$ of soil were placed. The test plant cultivated in the experiment was Miscanthus sachariflorus. Seedlings of Miscanthus were planted in the first year of the experiment. The obtained results show that the content of macronutrients: nitrogen, phosphorus, potassium in straw of Miscanthus sachariflorus was not dependent on the type of organic fertilizers used in the experiment. However, supplemental nitrogen-potassium fertilization significantly increases the content of potassium in the test plant in all three years of research and nitrogen in the second year.

The conducted research shows that the uptake of macronutrients depended on the dry matter yield quantity and the content of a given element in the yield. Within three years the straw of Miscanthus sacchariflorus took up the most of potassium $-11.63 \mathrm{~g}$ from the pot and the least of magnesium $1.20 \mathrm{~g}$ from the pot. The amount of the absorption of nitrogen, phosphorus and magnesium by the biomass of Miscanthus sacchariflorus from the pot on the objects fertilized with organic fertilizers was the highest in the second year of the research, which was a result of mineralization of the applied fertilizers.
\end{abstract}

Keywords: sewage sludge, composts prepared from sewage sludge, macronutrients, uptake of macronutrients, Miscanthus.

Presented at VII Conference Wasteless Technologies and Waste Management in Chemical Industry and Agriculture, Międzyzdroje, 12 - 15 June, 2007.

\section{INTRODUCTION}

A large pressure has recently been put on the development and modernization of the existing sewage treatment plants.

In the process of the purification of sewage there comes into being sewage-treatment water and sewage sludge. Sewage-treatment water is not a problem, because after purification it is piped away to natural water reservoirs or is used for the irrigation of agricultural plantations. However, problems occur with a rational management of sewage sludge, which is plentiful among waste. This waste can be environmentally managed, under the conditions of the processes of stabilization, where composting is the most popular. Due to composting sewage sludge can become valuable organic fertilizer.

On 16th February 2005 the Kyoto protocol came into effect. This is an international agreement, whose aim is to restraint the processes of global warming through the limitation, until the year 2012, the emission of greenhouse gases by about 5.25 in relation to the year 1990. The Kyoto protocol was signed and ratified by 141 countries, including Poland.

In Poland there is conducted research on the utilization of Chinese reed for the production of biomass. Biomass within the next few years can become an important source of renewable ecological energy, offering a huge chance of decreasing the burden for the natural environment and also for the mankind.

The aim of research was to define the impact of municipal sewage sludge and the composts prepared with its participation, on the content and uptake of macronutrients by the straw of Miscanthus sacchariflorus.

\section{MATERIALS AND METHODS}

The pot experiment was set up under the conditions of the hall of vegetation in 2002. The municipal sewage sludge and the composts produced with the GWDA method in 2001 based on municipal sewage sludge with the $30 \%$ addition of structuring materials, in conversion to the dry matter, were used in the experiment.

The pot experiment was set up with the split-split-plot method in three repetitions. The objects of the first factor were the doses of sewage sludge and composts $(1$ dose $=$ $13 \mathrm{~g}, 2$ dose $=26 \mathrm{~g}, 3$ dose $=39 \mathrm{~g}, 4$ dose $=52 \mathrm{~g}$ of dry matter in relation to the soil weight in the pot), the objects of the second factor were the types of organic fertilization (sewage sludge, 0.5-year compost prepared from sewage sludge, 1.5-year compost prepared from sewage sludge), the objects of the third factor were the vari- 
ants with and without nitrogen and potassium fertilization in the rates of $0.27 \mathrm{~g} \mathrm{~N}$ and $0.26 \mathrm{~g} \mathrm{~K}$ per pot.

In the second year of the experiment supplemental nitrogen-potassium fertilization was applied only on the objects which were fertilized with those components in the year of setting up the experiment. However, in the third year of the research nitrogen and potassium was applied on all the experimental objects and also phosphorus fertilization was used in the rate of $0.09 \mathrm{~g} P$ per pot. The experiment was conducted in Kick-Brauckmann`s pots of $9 \mathrm{dm}^{3}$ capacity in which $8 \mathrm{~kg}$ of soil were placed.

The chemical composition of the organic fertilizers applied in the experiment and the yield of the dry matter straw of Miscanthus were given in Table $\mathbf{1}^{\mathbf{1}}$.

The soil used in the experiment was from the Agricultural Experimental Station in Lipnik which belongs to the University of Agriculture in Szczecin. The soil was taken from an arable layer, it has the granulometric composition of the light loamy sand and was characterized by the neutral potential of hydrogen $\left(\mathrm{pH}_{\mathrm{KCl}} 6.75\right)$, a high content of available phosphorus and potassium as well as a low content of available magnesium. The test plant cultivated in the experiment was Miscanthus sachariflorus. Seedlings of Miscanthus were planted in the first year of the experiment.

The results of the macronutrients content were studied with an analysis of a variate method in the three-factor system of a complete randomization, carrying out triple interaction for testing the significance of the factors (doses of fertlizers $\mathrm{x}$ kind of fertilizers $\mathrm{x}$ two levels of fertilization with nitrogen and potassium). Confidence half-levels were specified for $\mathrm{p}=0.05$ using Tukey`s test.

\section{RESULTS AND DISCUSSION}

The content of nitrogen in the Chinese reed straw was diverse in the successive years of the investigations (table 2). In the first year, directly after the application of sewage sludge and composts it was the highest and it comprised from 4.19 to $9.19 \mathrm{~g} \cdot \mathrm{kg}^{-1} \mathrm{~d}$.m. The significantly higher con- tents of this element occurred only in the straw from the objects fertilized with sewage sludge.

However, the influence of increasing the doses and mineral fertilization on the content of nitrogen in the test plant was not affirmed. In the second year of the conducted research, the content of nitrogen in the straw amounted from 3.02 to $7.36 \mathrm{~g} \cdot \mathrm{kg}^{-1} \mathrm{~d} . \mathrm{m}$. The straw from the objects fertilized with nitrogen and potassium contained significantly more nitrogen, in comparison with the objects which had not been fertilized.

In the third year of the experiment, the concentration of nitrogen in the straw of Chinese reed was the lowest.

Increasing the doses of organic fertilizers caused a significant increase of the content of nitrogen in the straw of Chinese reed. The dose of 13 and $26 \mathrm{~g}$ per pot had a similar effect, however, the dose of $52 \mathrm{~g}$ caused a significant increase of the content of nitrogen in the straw.

The significantly higher contents of nitrogen occurred only in the straw of Chinese reed from the objects fertilized with sewage sludge.

The content of phosphorus in the straw of Chinese reed amounts from 0.49 to $0.98 \mathrm{~g} \cdot \mathrm{kg}^{-1} \mathrm{~s} . \mathrm{m} .{ }^{2}$. The results obtained in our own research show the two-, threefold higher content of that element (Table 2), with the variable interobjects dependences and in years.

According to Table 2, the content of potassium in the straw of Chinese reed in the following years of the research was decreasing. In the variants fertilized with nitrogen and potassium, the content of potassium in the straw of the test plant was significantly higher, in comparison with the objects without mineral fertilization.

Potassium is a very labile element which is present in all parts of the plant ${ }^{3}$.

An increase of the content of potassium in the plants in relation to the control object after an application of composts prepared from sewage sludge is in accordance with the earlier research ${ }^{4,5}$.

The content of macronutrients in the plants fertilized with composts does not depend on the type of the com-

Table 1. The chemical composition of the composts

\begin{tabular}{|c|c|c|c|c|}
\hline \multirow{2}{*}{\multicolumn{2}{|c|}{ Type of indication }} & \multicolumn{3}{|c|}{ Type of composts } \\
\hline & & $1^{*}$ & $2^{*}$ & $3^{*}$ \\
\hline \multicolumn{2}{|c|}{$\mathrm{DM}\left(\mathrm{g} \cdot \mathrm{kg}^{-1}\right)$} & 146 & 308 & 294 \\
\hline \multicolumn{2}{|c|}{ Reaction } & 7.7 & 7.2 & 7.3 \\
\hline Org. C & \multirow{3}{*}{$\mathrm{g} \cdot \mathrm{kg}^{-1} \mathrm{~d} \cdot \mathrm{m}}$. & 315 & 322 & 221 \\
\hline $\mathrm{N}-\mathrm{NH}_{4}$ & & 18.5 & 4.5 & 3.0 \\
\hline $\mathrm{N}-\mathrm{NO}_{3}$ & & 0,13 & 2,0 & 2.1 \\
\hline \multicolumn{5}{|c|}{ Total content } \\
\hline $\mathrm{N}$ & \multirow{6}{*}{$\mathrm{g} \cdot \mathrm{kg}^{-1} \mathrm{~d} \cdot \mathrm{m}$} & 57.2 & 15.9 & 10.1 \\
\hline $\mathrm{P}$ & & 12.3 & 6.1 & 7.8 \\
\hline $\mathrm{K}$ & & 1.41 & 6.70 & 6.00 \\
\hline $\mathrm{Ca}$ & & 19.2 & 5.60 & 4.40 \\
\hline $\mathrm{Mg}$ & & 4.50 & 4.15 & 3.98 \\
\hline $\mathrm{S}$ & & 5.69 & 3.71 & 4.85 \\
\hline \multicolumn{2}{|c|}{$C: N \quad(N=1)$} & 5.51 & 20.2 & 21.9 \\
\hline \multicolumn{2}{|c|}{$\mathrm{N}: \mathrm{P}: \mathrm{K}(\mathrm{N}=1)$} & $1: 0.21: 0.25$ & $1: 0.38: 0.42$ & $1: 0.77: 0.59$ \\
\hline $\mathrm{Cd}$ & \multirow{6}{*}{$\mathrm{mg} \cdot \mathrm{kg}^{-1} \mathrm{~d} . \mathrm{m}}$. & 1.65 & 1.63 & 1.76 \\
\hline $\mathrm{Fe}$ & & 425 & 280 & 394 \\
\hline $\mathrm{Mn}$ & & 207.5 & 97.1 & 102.2 \\
\hline $\mathrm{Ni}$ & & 67.7 & 53.9 & 41.1 \\
\hline $\mathrm{Pb}$ & & 48.5 & 32.5 & 30.4 \\
\hline $\mathrm{Zn}$ & & 492 & 272 & 384 \\
\hline
\end{tabular}


Table 2. The content of macronutrients in the straw of Miscanthus sacchariflorus $\left(\mathrm{g} \cdot \mathrm{kg}^{-1} \mathrm{~d} . \mathrm{m}.\right)$

\begin{tabular}{|c|c|c|c|c|c|c|c|c|c|c|c|c|}
\hline \multirow{2}{*}{ Objects } & \multicolumn{4}{|c|}{2002} & \multicolumn{4}{|c|}{2003} & \multicolumn{4}{|c|}{2004} \\
\hline & $\mathrm{N}$ & $\mathrm{P}$ & $\mathrm{K}$ & $\mathrm{Mg}$ & $\mathrm{N}$ & $\mathrm{P}$ & $\mathrm{K}$ & $\mathrm{Mg}$ & $\mathrm{N}$ & $\mathrm{P}$ & $\mathrm{K}$ & $\mathrm{Mg}$ \\
\hline $1^{*}$ & 5.18 & 2.52 & 23.17 & 1.85 & 4.16 & 2.07 & 11.77 & 1.07 & 3.42 & 3.30 & 6.32 & 1.00 \\
\hline $2^{*}$ & 5.51 & 2.44 & 22.02 & 1.72 & 4.60 & 2.07 & 12.56 & 1.14 & 3.80 & 3.42 & 3.14 & 1.25 \\
\hline $3^{*}$ & 6.17 & 2.45 & 18.76 & 1.66 & 5.44 & 2.09 & 14.35 & 1.42 & 4.07 & 3.15 & 6.01 & 1.33 \\
\hline $4^{*}$ & 7.78 & 2.55 & 19.75 & 1.91 & 6.56 & 2.08 & 15.07 & 1.63 & 4.58 & 3.06 & 6.59 & 1.50 \\
\hline $\mathrm{LSD}_{0.05}$ & n.s. & n.s. & 3.01 & n.s. & n.s. & 0.09 & n.s. & 0.34 & 0.54 & n.s. & n.s. & 0.265 \\
\hline Sewage sludge & 9.19 & 2.46 & 21.95 & 2.01 & 6.06 & 2.07 & 14.00 & 1.53 & 4.35 & 3.23 & 6.09 & 1.41 \\
\hline Compost 0.5 -year & 5.10 & 2.59 & 19.87 & 1.57 & 5.22 & 2.07 & 14.00 & 1.41 & 4.07 & 3.29 & 6.37 & 1.33 \\
\hline Compost 1.5-year & 4.19 & 2.43 & 20.97 & 1.39 & 4.30 & 2.09 & 12.31 & 1.00 & 3.49 & 3.18 & 6.32 & 1.07 \\
\hline $\mathrm{LSD}_{0,05}$ & 2.207 & n.s. & n.s. & 0.28 & n.s. & n.s. & n.s. & 0.26 & 0.42 & n.s. & n.s. & 0.203 \\
\hline Without fertilization NK & 5.67 & 2.58 & 19.98 & 1.53 & 3.02 & 2.10 & 7.90 & 1.10 & 3.88 & 3.49 & 5.63 & 1.01 \\
\hline With fertilization NK & 6.65 & 2.49 & 20.93 & 1.78 & 7.36 & 2.05 & 18.85 & 1.53 & 4.05 & 2.97 & 6.90 & 1.53 \\
\hline $\mathrm{LSD}_{0,05}$ & n.s. & n.s. & 1.50 & 0.18 & 1.53 & 0.04 & 2.09 & 0.17 & n.s. & 0.37 & 0.396 & 0.132 \\
\hline Mean & 6.16 & 2.50 & 20.82 & 1.71 & 5.19 & 2.08 & 13.42 & 1.31 & 3.97 & 3.23 & 5.93 & 1.27 \\
\hline Control & 3.08 & 2.14 & 19.67 & 1.07 & 3.32 & 1.87 & 5.50 & 1.34 & 2.45 & 2.70 & 4.25 & 0.73 \\
\hline Control+NK & 4.76 & 2.16 & 16.08 & 1.61 & 7.21 & 2.00 & 16.78 & 1.37 & 3.64 & 2.67 & 5.04 & 0.93 \\
\hline Mean & 3.92 & 2.15 & 17.88 & 1.34 & 5.26 & 1.94 & 11.34 & 1.36 & 3.05 & 2.69 & 4.65 & 0.83 \\
\hline
\end{tabular}

Table 3. Uptake of macronutrients by the straw of Miscanthus sacchariflorus (g from pot).

\begin{tabular}{|c|c|c|c|c|c|c|c|c|c|c|c|c|c|c|c|c|}
\hline \multirow{2}{*}{ Objects } & \multicolumn{4}{|c|}{2002} & \multicolumn{4}{|c|}{2003} & \multicolumn{4}{|c|}{2004} & \multicolumn{4}{|c|}{ Sum of $2002-2004$} \\
\hline & $\mathrm{N}$ & $P$ & $\mathrm{~K}$ & $\mathrm{Mg}$ & $\mathrm{N}$ & $P$ & $\mathrm{~K}$ & $\mathrm{Mg}$ & $\mathrm{N}$ & $P$ & $\mathrm{~K}$ & $\mathrm{Mg}$ & $\mathrm{N}$ & $P$ & $\mathrm{~K}$ & $\mathrm{Mg}$ \\
\hline $1^{*}$ & 1.30 & 0.64 & 5.84 & 0.47 & 1.42 & 0.71 & 4.02 & 0.36 & 0.65 & 0.62 & 1.19 & 0.19 & 3.37 & 1.97 & 11.05 & 1.02 \\
\hline $2^{*}$ & 1.43 & 0.63 & 5.72 & 0.45 & 1.61 & 0.72 & 4.40 & 0.40 & 0.74 & 0.66 & 0.61 & 0.24 & 3.78 & 2.01 & 10.73 & 1.09 \\
\hline $3^{*}$ & 1.75 & 0.69 & 5.31 & 0.47 & 1.90 & 0.80 & 5.47 & 0.54 & 0,92 & 0.71 & 1.35 & 0.30 & 4.57 & 2.17 & 12.13 & 1.31 \\
\hline $4^{*}$ & 2.17 & 0.71 & 5.51 & 0.53 & 2.50 & 0.73 & 5.29 & 0.57 & 1.02 & 0.68 & 1.47 & 0.33 & 5.69 & 2.12 & 12.27 & 1.43 \\
\hline Sewage sludge & 3.11 & 0.83 & 7.42 & 0.68 & 2.18 & 0.74 & 5.04 & 0.55 & 1.05 & 0.78 & 1.47 & 0.34 & 6.34 & 2.35 & 13.68 & 1.57 \\
\hline 0.5 -year compost & 1.23 & 0.63 & 4.81 & 0.38 & 1.84 & 0.73 & 4.94 & 0.50 & 0.78 & 0.63 & 1.22 & 0.26 & 3.85 & 1.99 & 10.97 & 1.14 \\
\hline 1.5-year compost & 0.94 & 0.55 & 4.72 & 0.31 & 1.52 & 0.74 & 4.36 & 0.35 & 0.66 & 0.60 & 1.19 & 0.20 & 3.12 & 1.89 & 10.27 & 0.86 \\
\hline Without fertilization NK & 1.47 & 0.67 & 5.19 & 0.40 & 1.15 & 0.80 & 3.02 & 0.42 & 0.66 & 0.59 & 0.95 & 0.17 & 3.28 & 2.06 & 9.16 & 0.99 \\
\hline With fertilization NK & 1.84 & 0.69 & 5.78 & 0.49 & 2.61 & 0.73 & 6.69 & 0.54 & 0.99 & 0.73 & 1.70 & 0.38 & 5.44 & 2.15 & 14.17 & 1.41 \\
\hline Mean & 1.69 & 0.67 & 5.59 & 0.46 & 1.86 & 0.74 & 4.80 & 0.47 & 0.83 & 0.67 & 1.24 & 0.27 & 4.38 & 2.08 & 11.63 & 1.20 \\
\hline Control & 0.58 & 0.40 & 3.72 & 0.20 & 1.10 & 0.62 & 1.82 & 0.44 & 0.18 & 0.20 & 0.31 & 0.053 & 1.86 & 1.22 & 5.85 & 0.69 \\
\hline Control+NK & 0.92 & 0.42 & 3.12 & 0.31 & 2.62 & 0.73 & 6.11 & 0.50 & 0.68 & 0.50 & 0.95 & 0.17 & 4.22 & 1.65 & 10.18 & 0.98 \\
\hline Mean & 0.75 & 0.41 & 3.42 & 0.26 & 1.86 & 0.68 & 3.96 & 0.47 & 0.43 & 0.35 & 0.63 & 0.11 & 3.04 & 1.44 & 8.01 & 0.62 \\
\hline
\end{tabular}

post. The successive activity of composts or increasing of its doses does not affect the increase of its content ${ }^{5,6,7}$.

On the basis of the obtained results (table 2) it was stated that the content of magnesium was decreasing in the following years of the research. Analysing the value of the obtained biomass of Chinese reed, insignificant interobjects diversity was noticed, however, the experimental factors (with the exception of increasing the doses of organic fertilizers in the first year of the research) had a significant impact on shaping the content of magnesium in the straw.

The amount of the absorbed macronutrients was calculated as a resultant of the dry matter yield and the content of this element in the yield.

The sum of nitrogen absorbed within three years of conducting the research on the straw of Chinese reed, varied from 3.12 to $6.34 \mathrm{~g}$ from the pot (Table 3 ). On the objects fertilized with sewage sludge the uptake was the highest and amounted to $6.34 \mathrm{gN}$ from the pot and the lowest was on the objects fertilized with the compost of the 1.5-year decomposition time.

By analysing the individual years of the research it was stated that the straw took the most nitrogen in 2003 (1.86 $\mathrm{g}$ from the pot) and the least in 2004 (0.83 $\mathrm{g}$ from the pot).

The content of phosphorus taken in by the straw of Chinese reed from the variants fertilized in the first and in the third year amounted to $0.67 \mathrm{~g}$ from the pot and in the second year $0.74 \mathrm{~g}$ from the pot. While considering the sum of the uptake from three years it was stated that the highest value of the uptake of phosphorus concerned the object fertilized with sewage sludge.

The uptake of potassium (table 3 ) in the following years of the research was decreasing, if we assume the uptake in 2002 for $100 \%$, then in 2003 the uptake decreased by $14.1 \%$ and in 2004 by $77.8 \%$. Supplemental mineral fertilization favourably influenced potassium uptake by the test plant.

During the three years of the research the highest amount of magnesium was taken in by the straw of Miscanthus sacchariflorus on the object fertilized with sewage sludge $-1.57 \mathrm{~g}$ from the pot (Table 3 ).

The diversity in amount of absorbed magnesium on the objects fertilized with the increasing doses of organic fertilizers in the following years of the research was shown. Supplemental nitrogen-potassium fertilization caused the increase of the uptake by the test plant. In the second year of the research the straw of the test plant took up the most of magnesium from the pot $-0.47 \mathrm{~g}$ it resulted from the mineralization of applied organic fertilizers ${ }^{\mathbf{8}}$.

\section{CONCLUSIONS}

1. The content of macronutrients: nitrogen, phosphorus, potassium in the straw of Miscanthus sacchariflorus was not dependent on the type of organic fertilizers used in the experiment.

2. Supplemental nitrogen-potassium fertilization significantly increased the content of potassium in the test plant 
in all the three years of the research and nitrogen in the second year.

3. The uptake of macronutrients depended on the dry matter yield quantity and the content of a given element in the yield. Within three years the straw of Miscanthus sacchariflorus took in the most of potassium $-11.63 \mathrm{~g}$ from the pot and the least of magnesium $1.20 \mathrm{~g}$ from the pot.

4. The amount of absorbed nitrogen, phosphorus and magnesium by the biomass of Miscanthus sacchariflorus from the pot on the objects fertilized with organic fertilizers was the highest in the second year of the research, which was a result of the mineralization of the applied fertilizers.

\section{LITERATURE CITED}

(1) Krzywy E., Wołoszyk Cz., Iżewska A.: Bezpośredni i następczy wpływ komunalnego osadu ściekowego i kompostów sporząadzonych z osadu ściekowego na wielkość plonu i zawartość mikropierwiastków w słomie trzciny chińskiej (Miscanthus sachariflorus). Zesz. Prob. Post. Nauk Rol., 2004, 502, $865-876$.

(2) Röhricht C., Beier T., Gross-Ophoff A.: Untersuchungen zur Anbaueignung und Ertragsfähigkeit von Miscanthus sinensis in Sachsen. Miscanthus- vom Anbau zur Verwertung, Tagung am $23-24.02 .2000$ in Bonn: 2000, $92-$ 96.

(3) Czuba R., Mazur T.: Wpływ nawożenia na jakość plonów. PWN Warszawa, 1988, 350).

(4) Filipek-Mazur B., Gondek K.: Ocena efektywności nawożenia kompostami z odpadów zielonych na podstawie plonowania, składu chemicznego i wykorzystania składników pokarmowych przez owies. Część I Azot, fosfor, potas. Zesz. Prob. Post. Nauk Rol., 2006, 512, $111-120$.

(5) Wołoszyk Cz.: Agrochemiczna ocena nawożenia kompostami z komunalnych osadów ściekowych i odpadami przemysłowymi. Rozp. AR Szczec., 2003, 217, 120 ss.

(6) Malinowska E., Kalembasa D, Jeżowski S.: Wpływ dawek azotu na plon i zawartość makroelementów w trawie Miscanthus sachariflorus uprawianej w doświadczeniu wazonowym. Zesz. Prob. Post. Nauk Rol., 2006, 512, 403 409.

(7) Stasiak M.: Trawa Miscanthus jako roślina wykorzystywana $\mathrm{w}$ bioremediacji energii odnawialnej. Ogólnopolskie seminarium studentów i doktorantów „Biotechnologia Środowiskowa” Wisła-Jarzębata, 8 10.12.2006 r. Politechnika Śląska w Gliwicach, 2006, 171 175.

(8) Gondek K., Filipek-Mazur B.: Ocena efektywności nawożenia kompostami z odpadów zielonych na podstawie plonowania, składu chemicznego i wykorzystania składników pokarmowych przez owies. Czesść II Zawartość i pobranie Ca, Mg, Na. Zesz. Prob. Post. Nauk Rol., 2006, 512, 129 137. 